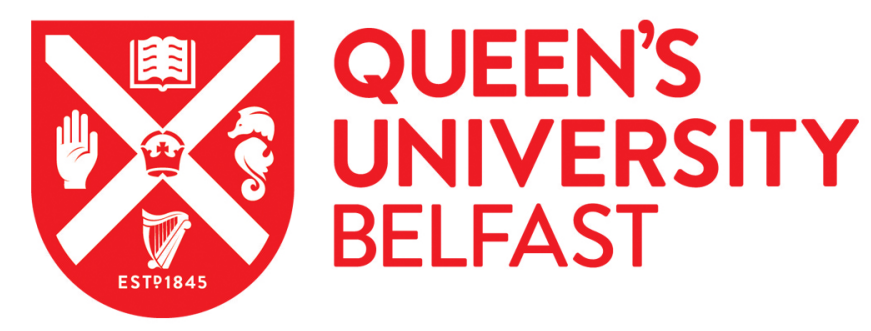

\title{
Ultrashort self-assembling Fmoc-peptide gelators for anti-infective biomaterial applications
}

McCloskey, A. P., Draper, E. R., Gilmore, B. F., \& Laverty, G. (2017). Ultrashort self-assembling Fmoc-peptide gelators for anti-infective biomaterial applications. Journal of peptide science, 23(2), 131-140.

https://doi.org/10.1002/psc.2951

Published in:

Journal of peptide science

Document Version:

Peer reviewed version

Queen's University Belfast - Research Portal:

Link to publication record in Queen's University Belfast Research Portal

\section{Publisher rights}

Copyright 2017 European Peptide Society and John Wiley \& Sons Ltd.

This work is made available online in accordance with the publisher's policies. Please refer to any applicable terms of use of the publisher.

\section{General rights}

Copyright for the publications made accessible via the Queen's University Belfast Research Portal is retained by the author(s) and / or other copyright owners and it is a condition of accessing these publications that users recognise and abide by the legal requirements associated with these rights.

Take down policy

The Research Portal is Queen's institutional repository that provides access to Queen's research output. Every effort has been made to ensure that content in the Research Portal does not infringe any person's rights, or applicable UK laws. If you discover content in the Research Portal that you believe breaches copyright or violates any law, please contact openaccess@qub.ac.uk. 
Ultrashort self-assembling Fmoc-peptide gelators for anti-infective biomaterial applications

Short title: Fmoc-peptides demonstrate selective activity against biofilms

Alice P. McCloskey ${ }^{1}$, Emily R. Draper ${ }^{2}$, Brendan F. Gilmore ${ }^{1}$, Garry Laverty ${ }^{1 *}$

1. Biofunctional Nanomaterials Group,

School of Pharmacy,

Medical Biology Centre,

Queen’s University Belfast,

97 Lisburn Rd,

Belfast,

N. Ireland,

BT9 7BL

Tel: +44 (0) 2890972273

Email: garry.laverty@qub.ac.uk

Fax: +44 (0)289024 7794

2. Department of Chemistry,

University of Liverpool,

Liverpool,

L69 7ZD,

U.K. 


\title{
Graphical abstract
}

\section{Sponsor}

This work was supported by the Queen's University Research Support Package for New Academic Staff for and a Royal Society Research Grant (RG150171) for GL. APM acknowledges funding provided by a N. Ireland Department of Employment and Learning $\mathrm{PhD}$ studentship grant. The manuscript was written through contributions of all authors. All authors have given approval to the final version of the manuscript. APM, ERD and BFG contributed equally. We acknowledge help from Prof. Dave Adams (University of Liverpool) for allowing us access to his Anton Paar Physica MCR301 rheometer for rheological studies.

\begin{abstract}
Biomaterial related infections have a significant impact on society and are a major contributor to the growing threat of antimicrobial resistance. Current licensed antibiotic classes struggle to breakdown or penetrate the exopolysaccharide biofilm barrier, resulting in sub-therapeutic concentrations of antibiotic at the surface of the biomaterial, treatment failure and increased spread of resistant isolates. This paper focuses for the first time on the ability of ultrashort Fmoc-peptide gelators to eradicate established bacterial biofilms implicated in a variety of medical device infections (Gram-positive: Staphylococcus aureus, Staphylococcus epidermidis and Gram-negative Escherichia coli, Pseudomonas aeruginosa). The effect of increasing the cationicity of the FmocFF via addition of di-lysine and di-orntithine was also studied with regard to antibacterial activity. Our studies demonstrated that Fmoc-peptides (FmocFF, FmocFFKK, FmocFFFKK, FmocFFOO) formed surfactant-like soft gels at concentrations of $1 \% \mathrm{w} / \mathrm{v}$ and above using a method of glucono- $\delta$-Lactone $\mathrm{pH}$ induction. The majority of Fmoc-peptides (0.5-2\% w/v) demonstrated selective action against established (grown for 24 hour) biofilms of Gram-positive and Gram-negative pathogens with FmocFF and FmocFFKK particularly promising. These results are likely to increase the clinical translation of short-peptide gelator platforms within the area of anti-infective biomaterials including as wound dressings and coatings for prostheses, catheters, heart valves and surgical tubes. In the long-term this will lead to wider treatment choices for clinicians and patients involved in the management of medical device infections and reduce the burden of antimicrobial resistance.
\end{abstract}


Keywords: Nanomaterial, biofilm, infection, bacteria, nosocomial, antimicrobial resistance

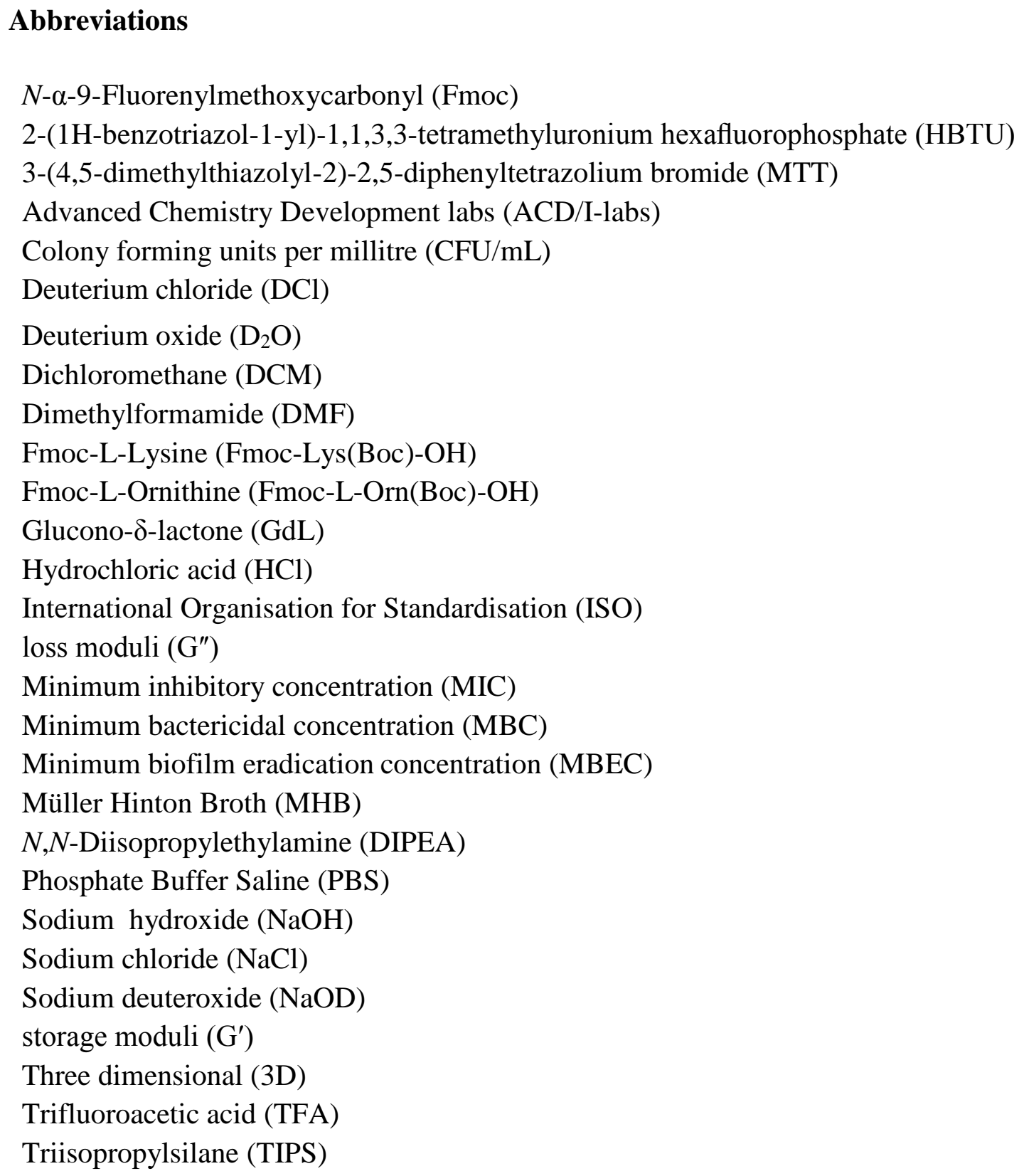

\section{Introduction}

Peptide nanomaterials are becoming increasingly prevalent throughout pharmaceutical research as an innovative solution to healthcare's greatest challenges, for example cancer [1], HIV/AIDs [2] and tissue engineering [3]. Of particular interest is the use of ultrashort peptides, composed of seven or less amino acid monomer units, with the ability to form 
supramolecular structures in response to changes in physiological stimuli ( $\mathrm{pH}$ [4], enzymes [5], ionic strength [6]). Ultrashort peptides are advantageous with respect to ease of synthesis, reduced cost compared to larger peptides/proteins used in biomedical therapies and are more accessible to upscale to manufacturing quantities for pharmaceutical applications [7]. The most studied of these ultrashort variants are the fluorenyl-9-methoxycarbonyl (Fmoc) dipeptides composed of a highly aromatic $\pi$-conjugate electron system attached to a variety of peptide sequences including leucine-glycine (LG), phenylalanine-glycine (FG) [8], tyrosine-threonine (YT), tyrosine-serine (YS), tyrosine-asparagine (YN) [9], tyrosine-leucine (YL) [10] and most notably di-phenylalanine (FF) [11]. Interest in Fmoc-peptides is primarily due to its common use as an amino acid protecting group in peptide synthesis and it has been successfully utilised as hydrogels for 3D tissue culture [12], within regenerative medicine [13], as sensors [14] and as a drug delivery platform [15].

Peptide hydrogels are promising molecules within the area of bacterial infection prevention and treatment $[9,16-18]$. Resistance to the current supply of antibiotics is increasing at an alarming rate and there has been a relative lack of alternative therapeutic strategies translating clinically. Biomaterial infection is a major contributor due in part to the development of a surface attached exopolysaccharide bacterial biofilm. This biofilm restricts penetration of antibiotics to the medical device surface resulting in increased tolerance to recommended therapeutic doses of antibiotics [19]. A number of synthetic hydrogel-based coating are currently utilised to prevent the growth of bacteria and biofilm development at the medical device surface [20]. Peptide hydrogels, demonstrating antibacterial properties, may serve as promising molecules to alleviate the burden of biomaterial infections. The ability of FmocFF peptide to eradicate biofilm formation has, to our knowledge, never previously been studied. This paper will assess whether FmocFF peptides and cationic ultrashort variants (FmocFFKK, FmocFFFKK, FmocFFOO) can eradicate preformed 24 hour biofilms of Grampositive (Staphylococcus aureus, Staphylococcus epidermidis) and Gram-negative (Escherichia coli, Pseudomonas aeruginosa) bacteria commonly implicated in biomaterial infections.

\section{Materials and methods}

\section{Peptide synthesis, purification and identification}


$N$ - $\alpha$-9-Fluorenylmethoxycarbonyl (Fmoc)-lysine and Fmoc-phenylalanine conjugated Wang resin, Fmoc-L-Phenylalanine (Fmoc-Phe-OH), Fmoc- $N$ - $\varepsilon-t$-Butyloxycarbonyl-L-Lysine (Fmoc-Lys(Boc)-OH), Fmoc-L-Ornithine (Fmoc-L-Orn(Boc)-OH), and 2-(1H-benzotriazol1-yl)-1,1,3,3-tetramethyluronium hexafluorophosphate (HBTU) were purchased from Merck Chemicals Ltd (Nottingham, U.K.). Piperidine, dichloromethane (DCM), methanol, diethyl ether, dimethylformamide (DMF), $N, N$-Diisopropylethylamine (DIPEA) were obtained from Sigma Aldrich (Dorset, U.K.). Trifluoroacetic acid (TFA), Triisopropylsilane (TIPS) and thioanisole were obtained from Tokyo Chemical Industry Ltd (Oxford, U.K.). FmocFF, FmocFFKK, FmocFFFKK and FmocFFOO (Figure 1) were synthesised using standard solidphase Fmoc peptide synthesis protocols using methods previously demonstrated by our group [4]. Peptides were cleaved from Wang resin, producing carboxylic acid terminated structures, via a mixture of $95 \%$ v/v TFA, $2.5 \%$ v/v TIPS and 2.5\% thioanisole (2 hours, room temperature). The identity of each peptide was confirmed via mass spectroscopy (Finnigan LCQ Ion Trap Mass Spectrometer, Thermo-Finnigan, San Jose, USA) (Table S1). Peptide purity was analysed via reverse-phase HPLC using an Agilent 1260 Infinity system, fitted with a Gemini $\mathrm{C}_{18}, 250 \mathrm{~mm} \times 4.6 \mathrm{~mm}$ column, a 100-80\% acetonitrile gradient (20 minutes) in $0.05 \%$ TFA water at a flow rate of $1.5 \mathrm{~mL} /$ minute. All peptides were found to have greater than $90 \%$ purity.

\section{pH-triggered peptide gelation via acid titration and glucono- $\delta$-lactone induction}

Fmoc-peptide hydrogels were prepared as previously outlined via $\mathrm{pH}$-triggered induction methods [21]. Two methods were studied to trigger gelation, namely titration with $0.5 \mathrm{M}$ hydrochloric acid $(\mathrm{HCl})$ and use of glucono- $\delta$-lactone $(\mathrm{GdL})$ induction. In order to minimize variation in peptide gel structure and strength, a series of formulation steps were carefully followed as outlined in Table 1 for $\mathrm{HCl}$ titration and Table 2 for GdL induction. The method of peptide hydrogel preparation has previously been demonstrated to be important in dictating the overall ability to form hydrogels and in particular their mechanical properties (strength, flow). Each Fmoc-peptide was suspended in deionised water and dissolved fully by the addition of $1 \mathrm{M}$ sodium hydroxide $(\mathrm{NaOH})$ resulting in an increase of $\mathrm{pH}$ to $\mathrm{pH} 9$. Subsequent reduction in $\mathrm{pH}$ via titration to $\mathrm{pH} 7$ using $0.5 \mathrm{M} \mathrm{HCl}$ enabled their ability to form hydrogels to be explored. The use of GdL was hypothesised to allow a slow and controlled reduction in $\mathrm{pH}$ of the peptide solution over time due to hydrolysis of GdL to D- 
gluconic acid [21]. Peptides were dissolved in $1.6 \mathrm{~mL}$ water and sonicated (Branson 3510 sonic bath, Branson Ultrasonics, Connecticut, USA) for 2 minutes at the highest setting $(42 \mathrm{KHz} \pm 6 \%)$. Addition of $1 \mathrm{M} \mathrm{NaOH}$ facilitated complete dissolution (pH 9). The stock solution was then made up to a final volume of $2 \mathrm{~mL}$ with water and GdL (10 mg) was added to this basic peptide solution. Changes in $\mathrm{pH}$ were monitored using Whatman $\mathrm{pH}$ indicator paper (pH 1-14) purchased from Sigma-Aldrich (Dorset, U.K.). Critical minimum gelation concentration (\% w/v) for each peptide was defined, where possible, by a gel inversion assay 24 hours after initial preparation to ensure full hydrogel development. Flow characteristics were used to determine peptides which formed gels or solutions. Gels remaining suspended and solutions demonstrating flow properties when inverted.

\section{Fourier transform infra-red spectroscopy}

FTIR spectra were utilized to study peptide secondary structures and were obtained using a Jasco 4000 series FTIR spectrometer (Jasco Inc. Tokyo, Japan) at a resolution of $2 \mathrm{~cm}^{-1}$ and a wavelength range of 4000-400 $\mathrm{cm}^{-1}$ (128 scans). Peptide samples were prepared as described above (Table 1) but using deuterated solvents, namely deuterium oxide $\left(\mathrm{D}_{2} \mathrm{O}\right)$, sodium deuteroxide $(\mathrm{NaOH})$ and deuterium chloride (DCl) (Sigma Aldrich, Gillingham, Dorset, U.K.). This was to eliminate strong overlapping absorption bands in the amide I region, at approximately $1640 \mathrm{~cm}^{-1}$, observed in the presence of standard water [22]. Peptide hydrogels/solutions were sandwiched between two $25 \mathrm{~mm}^{2}$ calcium fluoride discs (0.05 mm spacer). $\mathrm{A}_{2} \mathrm{O}, \mathrm{DCl}, \mathrm{NaOD}$ mixture was used as a background and subtracted from all spectra.

\section{Oscillatory rheology}

Rheological measurements were performed using an Anton Paar Physica MCR301 rheometer (St Albans, U.K.). A cup (7 mL Sterilin plastic sample vial, diameter $14.5 \mathrm{~mm}$ ) and fourblade vane $(8.5$ x $8.5 \mathrm{~mm})$ measuring system was used to perform frequency sweeps. For frequency $2 \mathrm{~mL}$ of the gels were prepared as described previously using the GdL induction method (Table 2) [21]. All experiments were performed at $25^{\circ} \mathrm{C}$ from $1-100 \mathrm{rad} \mathrm{s}^{-1}$ at a strain of $0.0003 \%$. 


\section{Biofilm susceptibility assay}

Fmoc-peptides were evaluated for their ability to reduce the viability of established biofilms (grown for 24 hours) of Gram-positive (S. epidermidis (ATCC 35984) and S. aureus (ATCC 29213)) and Gram-negative (P. aeruginosa (PAO1) and E. coli (ATCC 11303)) bacterial pathogens implicated in nosocomial and biomaterial related infections (obtained from LGC Standards, London, U.K.) as previous demonstrated by our group [4]. Bacterial cultures were prepared in Müller Hinton broth (MHB) and incubated in a gyro-rotary incubator at $37^{\circ} \mathrm{C}$ overnight prior to optically adjusted dilution to $2 \times 10^{6}$ colony forming units per $\mathrm{mL}$ $(\mathrm{CFU} / \mathrm{mL})$ in MHB. $100 \mu \mathrm{L}$ of each bacterial culture was placed in separate wells of sterile Nunc 96-well microtitre plates (VWR International, Leicestershire, U.K.). Biofilms were formed on the surface of the well over 24 hours under the shear stress (100 revolutions per minute) provided by a Gallenkamp gyrorotary incubator at $37^{\circ} \mathrm{C}$. After 24 hour incubation bacterial cultures were decanted and each microtitre well irrigated thrice with $200 \mu \mathrm{L}$ of sterile autoclaved $0.9 \% \mathrm{w} / \mathrm{v}$ sodium chloride $(\mathrm{NaCl})$ to remove non-adhered bacteria. Washed plates were gently tapped upside down on a sterile paper towel to remove residual wash. 100 $\mu \mathrm{L}$ of each Fmoc-peptide (0.5-2\% w/v) was introduced to each biofilm containing well and incubated for 24 hours at $37^{\circ} \mathrm{C}$ in a gyro-rotary incubator. Plates were again washed thrice with $0.9 \% \mathrm{w} / \mathrm{v} \mathrm{NaCl}$ and biofilm viability was determined using alamarBlue ${ }^{\circledR}$ (Biorad, Kidlington, U.K.) cell viability assay. A $20 \% \mathrm{v} / \mathrm{v}$ solution of alamarBlue ${ }^{\circledR}$ was prepared in MHB and $200 \mu \mathrm{L}$ was added to each well of the 96-well plates and incubated until fully developed and represented by a colour change from blue to pink (normally 2 hours for these bacterial isolates). Control wells included those containing bacteria only in PBS as the negative control (100\% survival) and $70 \%$ ethanol as the positive control (100\% kill). In a method previously outlined by our group hydroxyproyl methylcellulose (HPMC) was utilized as an inert non-antibacterial hydrogel control [17]. It was determined that the process of rinsing peptide hydrogels from the microtitre plate does not result in significant removal of adhered bacteria or adversely impact on biofilm viability. Developed plates were read at 570 nm using a Tecan Sunrise plate reader (Tecan Ltd, Reading, U.K.). The percentage reduction in biofilm viability was determined using the following equation.

$$
\% \text { reduction viability }=\left(\frac{A b s 570 n m \text { Peptide }- \text { Abs570nm PBS }}{\text { Abs570nm 70\% Ethanol }- \text { Abs570nm PBS }}\right) x 100
$$




\section{Haemolysis assay}

The ability of Fmoc-peptides to lyse mammalian cell membranes was established using a haemolysis assay commonly employed to study antimicrobial peptide toxicity [23]. $100 \mu \mathrm{L}$ of fresh equine erythrocytes (Laboratory supplies, Antrim, U.K.) were treated with $100 \mu \mathrm{L}$ of Fmoc-peptides $(0.5-2.0 \% \mathrm{w} / \mathrm{v})$ for 1 hour at $37^{\circ} \mathrm{C}$ in sterile Nunc 96 -well microtitre plates with six replicates at each concentration. Control wells included PBS (0\% haemolysis, negative control) and 0.1\% v/v Triton X-100 (100\% haemolysis, positive control, obtained from Sigma Aldrich, Dorset, U.K). After 1 hour incubation, erythrocytes were centrifuged at $1000 \mathrm{~g}$ in $1.5 \mathrm{~mL}$ Eppendorfs ${ }^{\circledR}$ (Sigma Aldrich, Dorset, U.K.) and aliquots of the supernatant used to determine haemoglobin released in a fresh 96-well microtitre plate read at $405 \mathrm{~nm}$ using a Tecan Sunrise plate reader and Equation 2 below.

$$
\% \text { Haemolysis }=\left(\frac{\text { Abs405nm Peptide }- \text { Abs405nm PBS }}{\text { Abs405nm 0.1\% TritonX }- \text { Abs } 405 m \text { PBS }}\right) \times 100
$$

\section{Cell viability assay}

The toxicity of Fmoc-peptides were also evaluated using a tissue culture cell viability assay and the International Organisation for Standardisation (ISO) biomaterial toxicity cell line NCTC L929 (ATCC CCL 1) murine fibroblast subcutaneous connective tissue (LGC Standards, London, U.K.) [4]. Minimum Essential Medium (MEM) containing L-glutamine, phenol red with Earle's Salts, supplemented with 1\% v/v penicillin/streptomycin and 10\% v/v horse serum was used as a culture medium (Invitrogen, Paisley, U.K.). Cells were incubated at $37{ }^{\circ} \mathrm{C}$ in an atmosphere of $5 \% \mathrm{CO}_{2}$ and subcultured at $80-90 \%$ confluency. Cells were cultured until at least third passage, inoculated at $1 \times 10^{4}$ cells per well in sterile Nunc 96-well microtitre plates and incubated for 24 hours. The media was removed and the surface attached cells exposed for 24 hours to $100 \mu \mathrm{L}$ of a range of Fmoc-peptide concentrations studied for $\mathrm{pH}$ triggered hydrogelation $(0.5-2 \% \mathrm{w} / \mathrm{v})$ with six replicates for each concentration. Controls included 70\% ethanol (100\% kill, positive control) and PBS (100\% viability, negative control). Cell viability was studied using alamarBlue ${ }^{\circledR}$ diluted to $10 \% \mathrm{v} / \mathrm{v}$ with supplemented MEM. The assay was allowed to develop for approximately 10 hours as 
optimal for the NCTC L929 cell line. Following development absorption was measured at $570 \mathrm{~nm}$ using a Tecan Sunrise plate reader and cell viability was calculated using Equation 3 below.

$$
\% \text { viability }=100-\left(\frac{\text { Abs570nm Peptide }- \text { Abs570nm PBS }}{\text { Abs570nm 70\%Ethanol }- \text { Abs570nm PBS }} \times 100\right)
$$

\section{Statistical analysis}

Statistical analyses were performed using GraphPad Prism 6. A Kruskal-Wallis test, with a Dunn's multiple comparisons test used to identify individual differences between reductions in biofilm viability for each Fmoc-peptide concentration relative to the negative PBS control. A Dunn's multiple comparisons test was also used to compare the biofilm eradication efficacy of same Fmoc-peptide at varying concentrations (2, 1.5, 1.0 and 0.5\%, same pathogen) and to compare the difference in biofilm eradication efficacy for each peptide at the same concentration (FmocFF, FmocFFKK, FmocFFFKK, FmocFFOO, same pathogen). A Kruskal-Wallis test, followed by a Dunn's multiple comparisons test was also utilised for statistical analysis relating to tissue culture cytotoxicity/cell viability data by comparison of percentage viability for the concentrations of Fmoc-peptides employed (2-0.5\% w/v) to the PBS negative control (100\% viability). Haemolysis data was also compared using similar statistical methods. Percentage haemolysis was compared to the negative PBS nonhaemolytic control which corresponded to $0 \%$ haemolysis. Kruskal-Wallis tests were employed rather than parametric Analysis of Variance (ANOVA) as data was shown to be non-normally distributed and therefore non-parametric using the Kolmogorov and Smirnov method. In all cases a probability of $\mathrm{p}<0.05$ denoted significance.

\section{Results and Discussion}

\section{Gel inversion assay}

Vial inversion provides a simple and quick assessment of the minimum critical gelation concentrations $[24,25]$. This data provides a range of concentrations relating to Fmoc 
hydrogelation that can then studied for antibiofilm activity. An increase in $\mathrm{pH}$ via addition of $1 \mathrm{M} \mathrm{NaOH}$ results in dissolution of Fmoc-peptides due ionisation of the carboxylic acid terminus. Addition of acid restores a proton to the carboxylate anion and has been previously reported to form homogenous FmocFF hydrogels at concentrations greater than $0.22 \% \mathrm{w} / \mathrm{v}$ and a pH less than 8 [12]. The rationale for studying two different methods of acidification is due to previous observations that $\mathrm{pH}$ triggered gelation is a kinetically driven process for short Fmoc peptides, whereby the rate of acidification significantly affects the form and strength of supramolecular hydrogels $[8,21]$. There was a difference in hydrogel formation between the two methods in terms of minimum critical gelation concentrations (\% w/v) for FmocFF (Table 3). HCl mediated gelation demonstrated difficulty with regard to forming homogenous hydrogels at previously reported concentrations for FmocFF with a minimum critical gelation concentrations of $1.5 \% \mathrm{w} / \mathrm{v}$. GdL induced gelation was consistent with previously reported critical gelation concentrations for FmocFF $(0.5 \%$ w/v, lowest concentration tested), providing evidence of a more sustained and kinetically favourable lowering of $\mathrm{pH}$ over time by slow hydrolysis of GdL to gluconic acid in the presence of water [8].

Peptide self-assembly is dependent upon hydrophobicity, steric hindrance and the ability of the peptide to hydrogen bond with both itself and the surrounding water molecules. The ability to form higher ordered structures, for example supramolecular hydrogels, is relative to the concentration of peptide residues present [26]. Consideration must also be given to the forces between the peptide and solvent (primarily water) at a molecular level and the hydrogen bonds that form between water molecules and hydrogen bond donators (amide bond) which tend to cause dissolution of peptide if above the optimal level required for gelation. As for all polymers, hydrogelation is a delicate balance between the forces that drive dissolution and those that govern precipitation [27]. Gazit proved that assembly occurs with the relatively hydrophobic dipeptide FF due to participation of its benzene ring motif in aromatic and $\pi-\pi$ interactions and forms a central role in our Fmoc-peptide motif [28]. Highly conjugated systems, for example the aromatic groups present in phenylalanine and Fmoc, are comprised of overlapping p electron orbitals. These groups are located on the $\mathrm{N}$ terminus and their nature enables $\pi$-stacking of Fmoc-peptide molecules. For this reason we decided to include an extra phenylalanine moiety to study its effect on hydrogelation. There was no significant difference observed in minimum critical gelation concentrations for FmocFFKK, FmocFFFKK and FmocFFOO with the formation of opaque white hydrogels at $1 \% \mathrm{w} / \mathrm{v}$ for 
both $\mathrm{pH}$ induction methods (Figure 2). Lysine and ornithine residues increase the hydrophilicity of the peptide motif, in theory, by possessing more hydrogen bond donators (primary amine R-group and extra amide bonds). These groups would also exist in a cationic form at physiological $\mathrm{pH}$, as $\mathrm{pH}$ would be less than the predicted $\mathrm{p} K_{\mathrm{a}}$ for the R-group primary amine of lysine (10.2-10.8) and ornithine (10.1-10.7), using the Advanced Chemistry Development labs (ACD/I-labs) $\mathrm{p} K_{\mathrm{a}}$ predictor. An expected increase in the minimum critical gelation concentration was not observed for cationic variants using $\mathrm{HCl}$ titration (Table 3). GdL induction is likely to be a truer reflection of the gelation process and is less prone to experimental deviations and artefacts due to $\mathrm{pH}$ related assembly kinetics [8, 21]. Therefore it was selected as the preferred method for gel preparation in the studies below.

\section{Fourier transform infrared spectroscopy}

FTIR enabled the peptide secondary structures of Fmoc-peptides to be determined and their resultant spectra are outlined in Figure 3. Analysis was performed at concentrations above the minimum critical gelation concentration for each peptide (2\% w/v). The FTIR spectra obtained indicate that the peptides self-assemble to form higher ordered $\beta$-sheet secondary structures as evidenced by the presence of discrete shoulders at $\sim 1570 \mathrm{~cm}^{-1}$ and a trough in transmittance at $\sim 1625 \mathrm{~cm}^{-1}$. Decrease in transmittance at $\sim 1675 \mathrm{~cm}^{-1}$ relates to antiparallel $\beta$ sheet formation. These observations correlate to what has been observed previously for FmocFF secondary structures and unsurprisingly confirm similar secondary structures for supramolecular peptide hydrogels containing basic amino acids [29].

\section{Oscillatory rheology}

Rheological analysis confirmed the Fmoc-peptides proved to be relatively poor gelators using the formulation guidelines outlined in Table 2. This resulted in the formation of surfactants of low viscosity as highlighted in Figure 4 . The loss moduli $\left(\mathrm{G}^{\prime \prime}\right)$ is consistently higher than the storage moduli $\left(\mathrm{G}^{\prime}\right)$ for each Fmoc-peptide. The highest value of gel strength FmocFF achieved was $\mathrm{G}^{\prime}$ of $46 \mathrm{~Pa}$ and was easily disrupted at low shear frequencies ( $\sim 2$ rads/s). Similar values were obtained when di-lysine (FmocFFKK), di-ornithine (FmocFFOO) and an extra phenylalanine (FmocFFFKK, data not shown) was incorporated into the FmocFF template. It is likely these relatively low values for elasticity can be attributed to the method 
of gel preparation (pH trigger) as demonstrated by the variation in gel strength for FmocFF preparations throughout the literature [30]. Smith and colleagues achieved a $\mathrm{G}^{\prime}$ of $10^{4} \mathrm{~Pa}$ by the slow addition of concentrated $\mathrm{HCl}$ [11]. The FmocFF peptides investigated by Tang demonstrated very weak gel elasticity, possessing a G' less than $1 \mathrm{~Pa}$. These were formulated by a combination of diluted $\mathrm{HCl}(0.085 \mathrm{M})$ heating to $75-80{ }^{\circ} \mathrm{C}$, vortexing and sonication [31]. Mixing and handling also highly influences the strength of Fmoc hydrogels [32]. A brief sonication step was introduced (Table 2) to our formulation, before addition of $1 \mathrm{M} \mathrm{NaOH}$, to increase breakdown of Fmoc-peptide aggregates and improve homogeneity. In spite of the low gel strength of our formulations low viscosity synthetic surfactants, including pluronics, have demonstrated potential for preventing bacterial attachment and biofilm formation when utilised as surface modifiers for model biomaterial surfaces [33, 34]. Therefore the antibiofilm activity of low viscosity Fmoc-peptides warrants further investigation.

\section{Biofilm susceptibility}

Biofilms are the key bacterial phenotype implicated in medical device infection and demonstrate increased tolerance to conventional antibiotics [35]. Our investigations centered on eradicating established preformed 24 hour biofilms of a broad-spectrum of pathogens implicated in a variety of medical device/biomaterial infections. Gram-positive S. aureus and S. epidermidis are causative pathogens of intravenous catheter, wound, prosthesis, endotracheal tubes and heart valve infections, whilst Gram-negative P. aeruginosa and E. coli are attributed to chronic wounds and implants that mediate gastro-intestinal and urinary function (e.g. urinary catheters) [20]. Fmoc conjugated hydrogels demonstrated broadspectrum antibiofilm activity with FmocFF in particular displaying significant activity against all pathogens at all concentrations tested $(0.5-2 \% \mathrm{w} / \mathrm{v})$ relative to the negative PBS control. Overall antibiofilm activity did not appear to concentration dependent for each of the individual Fmoc-peptides (FmocFF [Figure S3], FmocFFKK [Figure S4], FmocFFFKK [Figure S5], FmocFFOO [Figure S6] at the concentrations tested. Only FmocFFOO demonstrated significant differences in the percentage reduction in biofilm viability when the lowest concentration $(0.5 \% \mathrm{w} / \mathrm{v})$ and highest (2\% w/v) were directly compared for Grampositive (S. aureus and S. epidermidis) biofilm reduction. This is likely due to the relatively high concentrations of peptides tested with concentrations chosen based on previously reported critical gelation concentrations for FmocFF. For example the lowest concentration 
tested $(0.5 \% \mathrm{w} / \mathrm{v})$ corresponds to $5 \mathrm{mg} / \mathrm{mL}$ of peptide which is significantly higher than the reported minimum inhibitory (MIC), bactericidal (MBC) and biofilm eradication (MBEC) concentrations for our own ultrashort non-gelating lipopeptide Fmoc-OOWW- $\mathrm{NH}_{2}$ [23] and the functionalised Fmoc-cationic amphiphiles of the Das group [36]. These values were found to be in the microgram per $\mathrm{mL}$ range for many of the same species (S. aureus, E.coli, P. aeruginosa). We decided to focus on biofilm phenotypes due to their increased prevalence in clinical infection but also because obtaining true MIC values visually or spectrophotometrically within microtitre plates is often difficult with Fmoc gelators as hydrogelation and/or precipitation can often be misled for bacterial growth.

FmocFFFKK was the only peptide to display no significant biofilm reduction against any of the microorganisms tested at the highest concentration tested $(2 \% \mathrm{w} / \mathrm{v})$ when compared to the PBS negative control (Figure 5, 6, S1, S2). It was also the only Fmoc-peptide to demonstrate significant reduction in antibiofilm activity when compared directly to the same concentrations of FmocFFKK, FmocFFOO and particularly FmocFF (Figures S7-S10). There was evidence of peptide precipitation when FmocFFFKK hydrogels were prepared. This may have caused a reduction in the quantity of freely available peptide in solution and therefore a reduction in antibiofilm activity. Alteration in the hydrophobicity of these peptides may also have resulted impaired interaction with bacterial membranes and may explain why variable and less effective antibiofilm activity was observed in FmocFFFKK. A proposed optimal hydrophobicity of $40-60 \%$ has been suggested and excessive hydrophobicity, in this case through the introduction of an extra phenylalanine, may be associated with greatly reduced antimicrobial activity [37, 38].

FmocFFOO demonstrated significant reduction against only Gram-positive staphylococcal species at 2\% w/v (Figures 5 and S1). Only FmocFF showed significant reduction in biofilm viability for all isolates at $0.5 \% \mathrm{w} / \mathrm{v}$. Incubation with $2 \% \mathrm{w} / \mathrm{v}$ FmocFF resulted in significant mean viable biofilm reduction values greater than $90 \%$ for all pathogens (93\% S. aureus [Figure 5], 97\% E. coli [Figure 6] and 92\% for P. aeruginosa [Figure S2]). By comparing the findings of this work to that of Paladini, Debnath and Iwansyah who targeted planktonic bacteria, it can be seen that the FmocFF conjugates investigated in this work show promising activity against the more resistant biofilm forms [36, 39, 40]. FmocFFKK (2\% w/v) also demonstrates broad-spectrum activity with an $82 \%$ reduction in viable E. coli and S. aureus biofilms. It may be possible that improved viscosity may increase the ability to bind and trap bacterial biofilm cells. FmocFF, prepared by GdL induction, is the only Fmoc-peptide to 
possess at critical gelation concentration below $1 \% \mathrm{w} / \mathrm{v}(0.5 \% \mathrm{w} / \mathrm{v}$, Table 3$)$. Some investigations have discovered that assembly state, structural conformation, molecular folding and bulk mechanical properties are important in conferring antibacterial activity to hydrogels [2, 41-43]. Li and colleagues recently developed an anion sponge which enabled interaction with negatively charged structures in bacterial membranes resulting in cell lysis due to the cationic nature and detergent-like effects of their hydrogel [43]. Hydrogelation alone is unlikely to be a significant factor to eradicate biofilms, for example by limiting the movement and availability of nutrients and mediators of biomolecular processes. This is especially true for biofilms whereby bacteria successfully exist within the soft extracellular polymeric architecture of the biofilm matrix. The lack of efficacy of HPMC hydrogel controls in previous studies by our group also reduces the likelihood that hydrogelation is a standalone factor for antibacterial activity [4].

FmocFF peptides have been utilised previously as a platform for antibacterial drug delivery but mainly against more antibiotic susceptible, free-flowing planktonic phenotype. A study by Paladini and colleagues utilised FmocFF hydrogels as a delivery system for $2 \%$ silver nanoparticles [39]. This resulted in a 99\% reduction in the planktonic form of S. aureus with the investigators hypothesising a potential use for this as technology a wound dressing. However the study utilised silver nanoparticles as the active antibacterial molecule, whereas FmocFF served as a biologically inert medium. A similar study by Debnath investigated the antibacterial activity of a range of Fmoc-peptide pyridinium-functionalised cationic amphiphiles [36]. They discovered these molecules to be active against a broad-spectrum of planktonic bacteria, namely $S$. aureus, E. coli and P. aeruginosa. This is likely due to detergent-like effects of cationic hydrogels when in contact with hydrophobic anionic bacterial cell membranes as proven previously for Fmoc phenylalanine and leucine peptide co-assemblies [40]. This phenomenon is also observed in the antimicrobial activity of other notable self-assembling peptides platforms, for example Schneider's group MAX and ARG peptide gelators [18, 44]. From our results we also believe that the FmocFF motif is responsible for introducing toxicity and antimicrobial activity to the peptide most likely due to its high aromaticity and surfactant-like properties. The introduction of cationic species has negligible effects on antibiofilm activity when direct statistical comparisons are made at the same concentrations and bacterial species (Figures S3-S6). 


\section{Haemolysis and cell viability}

With the rise of nanotechnology and increased possibilities with regard to their use as therapeutics it has become critically important that their relative toxicity profiles are fully defined. The haemolysis assay provides a rapid visual indicator of the membrane-targeted toxicity of antimicrobial peptides. It has additional importance in the context of this work as the potential future applications of these Fmoc-peptides is as antimicrobial coatings for intravenous catheters where interaction with blood components, including red blood cells, is prevalent. The Fmoc peptides (Figure 7) demonstrated significant haemolytic activity across the majority of concentrations tested. Only $1 \%$ and $0.5 \% \mathrm{w} / \mathrm{v}$ FmocFFKK demonstrated no significant haemolysis relative to the negative PBS control $(0.5 \% \mathrm{w} / \mathrm{v}: 19.9 \%$ haemolysis, $1 \%$ $\mathrm{w} / \mathrm{v}: 25.8 \%$ haemolysis). These are relatively high values compared to previous values relating to cationic antimicrobial peptides investigated by our group, however as with antimicrobial investigations the concentrations in this study are in the milligram per $\mathrm{mL}$ range rather than microgram per $\mathrm{mL}$ concentrations of previous studies [4], [45]. It is likely that the hydrophobicity of the aromatic Fmoc and phenylalanine motifs is providing significant scope for hydrophobic interactions with lipids present in the membrane of erythrocytes resulting in significant haemolysis. Investigations involving the self-assembling peptide RADA16-1 show that not all peptides are in fact haemolytic. RADA16-1 demonstrated haemostatic activity with entrapment of blood components within nanofibres forming a morphologically similar fibrebased clot to fibrin clots formed in the traditional blood-clotting cascade [47]. This highlights the potential benefit of assembling peptides as topical biomaterials for wound healing and as therapies for haemorrhagic conditions [48]. The haemolysis (Figure 7) and NCTC 929 cell cytotoxicity (Figure 8) results are not in good agreement. Whilst the haemolysis assay provides a good reflection of membrane toxicity, cell cytotoxicity via tissue culture analysis provides a more accurate reflection of the influence of Fmoc-peptides on the erythrocytes. The major limitation of haemolysis assays are that it is susceptible to osmotic variations in the test media. Fmoc-peptides were formulated according to the method of GdL induction (Table 2) whereby deionised water formed the majority of solvent. It may be possible that the hypo-tonicity of these peptide-deionised water mixtures may have contributed to increased haemolysis relative to the iso-osmolar PBS negative control. Research by Bucki demonstrated antimicrobial peptides (e.g. LL37) that do not damage human cells in isotonic solutions could be rendered hemolytic under hypo-osmotic conditions [49]. Tissue culture analysis using the NCTC 929 
cell line is also the preferred International Standard (ISO 10993-5) in vitro test for cytotoxicity of polymeric biomaterials [50].

The peptide conjugates variable cell cytotoxicity with no significant difference in cell viability for most compared to the PBS negative control. FmocFFFKK is the only peptide to demonstrate significant reduction in cell viability at $1 \% \mathrm{w} / \mathrm{v}$ and above. There remains preferential toxicity for bacterial biofilms rather than mammalian NCTC 929 cells as a result of greater loss of viability in bacterial cells (Figures, 5, 6, S1, S2, 8). This may be because mammalian cell membranes possess a high concentration of cholesterol along with phosphatidylethanolamine, phosphatidylcholine and sphingomyelin rendering them with neutrally charged [51]. It has also previously been demonstrated by our group that these properties result in cationic peptides having reduced selectivity for mammalian cells in comparison to negatively charged bacterial cells [4, 23, 45, 52]. Both FmocFF and FmocFFKK demonstrated highest cell viability above $60 \%$ at all concentrations tested. FmocFF has been widely investigated but doubts remain as to its inherent toxicity due to the presence of the highly aromatic Fmoc group and it's similarities to notoriously toxic drugs such as tricyclic antidepressants. Although at $2 \% \mathrm{w} / \mathrm{v}$ FmocFF, FmocFFKK and FmocFFKK percentage cell viability were shown not to be significantly different than PBS their respective mean values of 62, 66 and 59\% cell viability would warrant concern for their clinical translation. Questions remain as to whether this is a suitable level of toxicity to warrant bacterial biofilm reduction. As with any antimicrobial, for clinical translation to proceed the regulatory authorities involved in drug/biomaterial development require evidence that antibacterial efficacy far outweighs concerns regarding toxicity. Only truly randomised controlled clinical trials in afflicted human subjects can provide such assurance with data compared to placebo and market leading antibiotic/biomaterial controls. Tissue culture toxicity studies within the literature demonstrate variable cell toxicity and appeared to be dependent on the cell line studied. The Gazit group examined the toxicity of FmocFF and its derivatives against Chinese hamster ovary cells. Cells were exposed for 24 hours and examined using a 3-(4,5-dimethylthiazolyl-2)-2,5-diphenyltetrazolium bromide (MTT) assay to confirm viability. Similar to our own tissue culture viability studies, cells that weregrown on a $500 \mu \mathrm{L}(0.5 \% \mathrm{w} / \mathrm{v})$ peptide hydrogel scaffold and demonstrated excellent viability (>90\%) [53]. The Ulijn group also investigated cytocompatibility of $20 \mathrm{mM}$ FmocFF and FmocFFK hydrogel mixes for the primary purpose of using them as potential cell culture matrices. FmocFF and FmocFFK exhibited excellent survival following 48 hours treatment 
using bovine chondrocytes (100\%) but mean viability was reduced substantially when 3T3 murine fibroblast cells (38\%) and human dermal fibroblast ( 15\%) cells were studied [24]. The authors concluded that varying mechanical properties and chemical functionalities across the Fmoc-peptides affected cell survival across a variety of cell types. In the case of FmocFF and FmocFFK improved chondrocyte viability linked to enhanced protein adsorption, as commonly observed on charged surfaces [54]. Tailoring and modification of Fmoc-peptide hydrogels may improve their selectivity for bacterial cells further. The versatility of the peptide motif and wealth of functional groups means that localised delivery to infection sites and triggering of antibacterial activity/hydrogelation in response to a specific bacterial signal (enzyme, $\mathrm{pH}$ change) remains a real possibility and may serve as the most optimal method to reduce damage to healthy cells and tissue. Parenteral antimicrobial peptides currently do not have a successful record in the clinical trial arena due to systemic toxicity and issues relating to biostability [7]. Therefore the first antimicrobial peptide-hydrogel product is likely to be for more localised administration, whereby infection occurs at a single site such as wound or at the surface of a medical implant. The decreased size of the ultrashort Fmoc-peptide motif relative to larger antimicrobial peptide gelators means that they have increased potential to be translated for the benefit of real patients due to more cost-effective pharmaceutical upscale.

\section{Conclusions}

In summary, the results obtained in this study show the therapeutic potential of ultrashort Fmoc-peptides in the treatment and prevention of biomaterial related infections. However, as demonstrated particularly by the haemolysis results, concerns still exist with regard to the true long-term toxicity of the Fmoc-peptide motif. The Fmoc-peptides studied possess excellent activity against the most antibiotic resistant biofilm phenotype of bacteria. Their use may be superseded by other related ultrashort motifs, for example the naphthalene-peptides, which do not share the same level of concern with regard to toxicity as the Fmoc peptides due to their use throughout many licensed pharmaceutical formulations including the beta-blocker propranolol [4, 27]. However, this work provides an example of broad-spectrum antibacterial peptide gelators and is a step forward with regard to their use in biomaterial applications (wound dressings, medical implants, prostheses), thereby increasing the available treatment options to those involved in managing medical device infections and limiting the increasing 
threat of antimicrobial resistance which is having a increasingly detrimental impact on society.

\section{References}

[1] Zhou, J.; Du, X.; Yamagata, N.; Xu, B. Enzyme-instructed self-assembly of small Dpeptides as a multiple-step process for selectively killing cancer cells. J. Am. Chem. Soc. 2016, 138, 3813-3823.

[2] Li, J.Y.; Li, X.; Kuang, Y.; Gao, Y.; Du, X.; Shi, J.; Xu, B. Self-delivery multifunctional anti-HIV hydrogels for sustained release. Adv. Healthc. Mater. 2013, 2, 1586-1590.

[3] Koutsopoulos, S. Self-assembling peptide nanofiber hydrogels in tissue engineering and regenerative medicine: progress, design guidelines, and applications. J. Biomed. Mater. Res. A. 2016, 104, 1002-1016.

[4] Laverty, G.; McCloskey, A.P.; Gilmore, B.F.; Jones, D.S.; Zhou, J.; Xu, B. Ultrashort cationic naphthalene-derived self-assembled peptides as antimicrobial nanomaterials. Biomacromolecules. 2014, 15, 3429-3439.

[5] Zhou, J.; Xu, B. Enzyme-instructed self-assembly: a multistep process for potential cancer therapy. Bioconjug. Chem. 2015, 26, 987-999.

[6] Thota, C.K.; Yadav, N.; Chauhan, V.S. A novel highly stable and injectable hydrogel based on a conformationally restricted ultrashort peptide. Sci. Rep. 2016, 6, 31167.

[7] Rafferty, J.; Nagaraj, H.; McCloskey, A.P.; Huwaitat, R.; Porter, S.; Albadr, A.; Laverty, G. Peptide Therapeutics and the Pharmaceutical Industry: Barriers Encountered Translating from the Laboratory to Patients. Curr. Med. Chem. 2016. 23, 1-29.

[8] Adams, D.J.; Mullen, L.M.; Berta, M.; Chen, L.; Frith, W.J. Relationship between molecular structure, gelation behaviour and gel properties of Fmoc-dipeptides. Soft Matter. 2010, 6, 1971-1980.

[9] Hughes, M.; Birchall, L.S.; Zuberi, K.; Aitken, L.A.; Debnath, S.; Javida, N.; Ulijn, R.V. Differential supramolecular organisation of Fmoc-dipeptides with hydrophilic terminal amino acid residues by biocatalytic self-assembly. Soft Matter. 2012, 8, 11565-11574.

[10] Fleming, S.; Debnath, S.; Frederix, P.W.; Tuttle, T.; Ulijn, R.V. Aromatic peptide amphiphiles: significance of the Fmoc moiety. Chem. Commun. 2013, 49, 10587-10589. 
[11] Smith, A.M.; Williams, R.J.; Tang, C.; Coppo, P.; Collins, R.F.; Turner, M.L.; Saiani, A.; Ulijn, R.V. Fmoc-diphenylalanine self assembles to a hydrogel via a novel architecture based on $\pi-\pi$ interlocked $\beta$-sheets. Adv. Mater. 2008, 20, 37-41.

[12] Jayawarna, V.; Ali, M.; Jowitt, T.; Miller, A.; Saiani, A.; Gough, J.; Ulijn, R.

Nanostructured hydrogels for three-dimensional cell culture through self-assembly of fluorenylmethoxycarbonyl-dipeptides. Adv Mater. 2006, 18, 611-614.

[13] Zhou, M.; Ulijn, R.V.; Gough, J.E. Extracellular matrix formation in self-assembled minimalistic bioactive hydrogels based on aromatic peptide amphiphiles. J. Tissue Eng. 2014, 5, 2041731414531593.

[14] Lian, M.; Chen, X.; Lu, Y.; Yang, W. Self-assembled peptide hydrogel as a smart biointerface for enzyme-based electrochemical biosensing and cell monitoring. ACS Appl. Mater. Interfaces. 2016.

[15] Ischakov, R.; Adler-Abramovich, L.; Buzhansky, L.; Shekhter, T.; Gazit, E. Peptidebased hydrogel nanoparticles as effective drug delivery agents. Bioorg. Med. Chem. 2013, 21, 3517-3522.

[16] Schneider, J.P.; Pochan, D.J.; Ozbas, B.; Rajagopal, K.; Pakstis, L.; Kretsinger, J. Responsive hydrogels from the intramolecular folding and self-assembly of a designed peptide. J. Am. Chem. Soc. 2002, 124, 15030-15037.

[17] Zhang, Y.; Kuang, Y.; Gao, Y.; Xu, B. Versatile small-molecule motifs for selfassembly in water and the formation of biofunctional supramolecular hydrogels. Langmuir. 2011, 27, 529-537.

[18] Salick, D.A.; Kretsinger, J.K.; Pochan, D.J.; Schneider, J.P. Inherent antibacterial activity of a peptide-based Beta-hairpin hydrogel. J. Am. Chem. Soc. 2007, 129, 1479314799.

[19] McCloskey, A.P.; Gilmore, B.F.; Laverty, G. Evolution of antimicrobial peptides to selfassembled peptides for biomaterial applications. Pathogens. 2014, 3, 791-821.

[20] Laverty, G.; Gorman, S.P.; Gilmore, B.F. Biofilms and implant-associated infections. In Biomaterials and Medical Device-Associated Infections, First Edition ed.; Barnes, L. and Cooper, I.R., Eds.; Woodhead Publishing: Waltham, MA, 2015, pp. 19-46.

[21] Adams, D.J.; Butler, M.F.; Frith, W.J.; Kirkland, M.; Mullen, L.; Sanderson, P. A new method for maintaining homogeneity during liquid-hydrogel transitions using low molecular weight hydrogelators. Soft Matter. 2009, 5, 1856-1862.

[22] Kong, J.; Yu, S. Fourier transform infrared spectroscopic analysis of protein secondary structures. Acta Biochim. Biophys. Sin. 2007, 39, 549-559. 
[23] Laverty, G.; McLaughlin, M.; Shaw, C.; Gorman, S.P.; Gilmore, B.F. Antimicrobial activity of short, synthetic cationic lipopeptides. Chem. Biol. Drug Des. 2010, 75, 563-569. [24] Jayawarna, V.; Richardson, S.M.; Hirst, A.R.; Hodson, N.W.; Saiani, A.; Gough, J.E.; Ulijn, R.V. Introducing chemical functionality in Fmoc-peptide gels for cell culture. Acta Biomater. 2009, 5, 934-943.

[25] Du, X.; Zhou, J.; Shi, J.; Xu, B. Supramolecular hydrogelators and hydrogels: from soft matter to molecular biomaterials. Chem. Rev. 2015, 115, 13165-13307.

[26] Caplan, M.R.; Schwartzfarb, E.M.; Zhang, S.; Kamm, R.D.; Lauffenburger, D.A. Control of self-assembling oligopeptide matrix formation through systematic variation of amino acid sequence. Biomaterials. 2002, 23, 219-227.

[27] Yang, Z.; Liang, G.; Wang, L.; Xu, B. Using a kinase/phosphatase switch to regulate a supramolecular hydrogel and forming the supramolecular hydrogel in vivo. J. Am. Chem. Soc. 2006, 128, 3038-3043.

[28] Gazit, E. Self-Assembled Peptide Nanostructures: The design of molecular building blocks and their technological utilization. Chem. Soc. Rev. 2007, 36, 1263-1269.

[29] Huang, R.; Wei, Q.; Feng, L.; Su, R.; He, Z. Self-assembling peptide-polysaccharide hybrid hydrogel as a potential carrier for drug delivery. Soft Matter. 2011, 7, 6222-6230. [30] Raeburn, J.; Zamith Cardoso, A.; Adams, D.J. The importance of the self-assembly process to control mechanical properties of low molecular weight hydrogels. Chem. Soc. Rev. 2013, 42, 5143-5156.

[31] Tang, C.; Smith, A.M.; Collins, R.F.; Ulijn, R.V.; Saiani, A. Fmoc-diphenylalanine selfassembly mechanism induces apparent pKa shifts. Langmuir. 2009, 25, 9447-9453.

[32] Helen, W.L.P.; Ulijn, R.V.; Gough, J.; Tirelli, N. Mechanosensitive peptide gelation: mode of agitation controls mechanical properties and nano-scale morphology. Soft Matter. 2011, 7, 1732-1740.

[33] Bridgett, M.J.; Davies, M.C.; Denyer, S.P. Control of staphylococcal adhesion to polystyrene surfaces by polymer surface modification with surfactants. Biomaterials. 1992, 13, 411-416.

[34] Mogen, A.B.; Chen, F.; Ahn, S.J.; Burne, R.A.; Wang, D.; Rice, K.C. PluronicsFormulated farnesol promotes efficient killing and demonstrates novel interactions with Streptococcus mutans biofilms. PLoS One. 2015, 10, e0133886.

[35] Donlan, R.M. Biofilms and device-associated infections. Emerg. Infect. Dis. 2001, 7, 277-281. 
[36] Debnath, S.; Shome, A.; Das, D.; Das, P.K. Hydrogelation through self-assembly of Fmoc-peptide functionalized cationic amphiphiles: potent antibacterial agent. J Phys Chem B. 2010, 114, 4407-4415.

[37] Strempel, N.; Strehmel, J.; Overhage, J. Potential application of antimicrobial peptides in the treatment of bacterial biofilm infections. Curr. Pharm. Des. 2015, 21, 67-84.

[38] Edwards, I.A.; Elliott, A.G.; Kavanagh, A.M.; Zuegg, J.; Blaskovich, M.A.; Cooper, M.A. Contribution of amphipathicity and hydrophobicity to the antimicrobial activity and cytotoxicity of Beta-hairpin peptides. ACS Infect. Dis. 2016, 2, 442-450.

[39] Paladini, F.; Meikle, S.T.; Cooper, I.R.; Lacey, J.; Perugini, V.; Santin, M. Silver-doped self-assembling di-phenylalanine hydrogels as wound dressing biomaterials. J. Mater. Sci. Mater. Med. 2013, 24, 2461-2472.

[40] Irwansyah, I.; Li, Y.Q.; Shi, W.; Qi, D.; Leow, W.R.; Tang, M.B.; Li, S.; Chen, X. Gram-positive antimicrobial activity of amino acid-based hydrogels. Adv Mater. 2015, 27, 648-654.

[41] Ng, V.W.; Chan, J.M.; Sardon, H.; Ono, R.J.; Garcia, J.M.; Yang, Y.Y.; Hedrick, J.L. Antimicrobial hydrogels: a new weapon in the arsenal against multidrug-resistant infections. Adv. Drug Deliv. Rev. 2014, 78, 46-62.

[42] Xu, D.; Jiang, L.; Singh, A.; Dustin, D.; Yang, M.; Liu, L.; Lund, R.; Sellati, T.J.; Dong, H. Designed supramolecular filamentous peptides: balance of nanostructure, cytotoxicity and antimicrobial activity. Chem. Commun. 2015, 51, 1289-1292.

[43] Li, P.; Poon, Y.F.; Li, W.; Zhu, H.Y.; Yeap, S.H.; Cao, Y.; Qi, X.; Zhou, C.; Lamrani, M.; Beuerman, R.W. et al. A Polycationic antimicrobial and biocompatible hydrogel with microbe membrane suctioning ability. Nat. Mater. 2011, 10, 149-156.

[44] Salick, D.A.; Pochan, D.J.; Schneider, J.P. Design of an injectable $\beta$-hairpin peptide hydrogel that kills methicillin-resistant Staphylococcus aureus. Adv. Mater. 2009, 21, 41204123.

[45] Laverty, G.; Gorman, S.P.; Gilmore, B.F. The potential of antimicrobial peptides as biocides. Int. J. Mol. Sci. 2011, 12, 6566-6596.

[46] Kacprzyk, L.; Rydengard, V.; Morgelin, M.; Davoudi, M.; Pasupuleti, M.; Malmsten, M.; Schmidtchen, A. Antimicrobial activity of histidine-rich peptides is dependent on acidic conditions. Biochim. Biophys. Acta. 2007, 1768, 2667-2680.

[47] Hsu, B.B.; Conway, W.; Tschabrunn, C.M.; Mehta, M.; Perez-Cuevas, M.B.; Zhang, S.; Hammond, P.T. Clotting mimicry from robust hemostatic bandages based on self-assembling peptides. ACS Nano. 2015, 9, 9394-9406. 
[48] Saini, A.; Serrano, K.; Koss, K.; Unsworth, L.D. Evaluation of the hemocompatibility and rapid hemostasis of (RADA) 4 peptide-based hydrogels. Acta Biomater. 2016, 31, 71-79. [49] Bucki, R.; Janmey, P.A. Interaction of the gelsolin-derived antibacterial PBP 10 peptide with lipid bilayers and cell membranes. Antimicrob. Agents Chemother. 2006, 50, 2932-2940. [50] International standard ISO 10993-5. Biological Evaluation of Medical Devices Part 5: Tests for Cytotoxicity: in vitro Methods. 2009.

[51] Kamimori, H.; Blazyk, J.; Aguilar, M.I. Lipid membrane-binding properties of tryptophan analogues of linear amphipathic Beta-sheet cationic antimicrobial peptides using surface plasmon resonance. Biol. Pharm. Bull. 2005, 28, 148-150.

[52] Laverty, G.; McCloskey, A.P.; Gorman, S.P.; Gilmore, B.F. Anti-biofilm activity of ultrashort cinnamic acid peptide derivatives against medical device-related pathogens. $J$. Pept. Sci. 2015, 21, 770-778.

[53] Mahler, A.; Reches, M.; Rechter, M.; Cohen, S.; Gazit, E. Rigid, Self-assembled hydrogel composed of a modified aromatic dipeptide. Adv. Mater. 2006, 18, 1365-1370. [54] Faucheux, N.; Schweiss, R.; Lutzow, K.; Werner, C.; Groth, T. Self-assembled monolayers with different terminating groups as model substrates for cell adhesion studies. Biomaterials. 2004, 25, 2721-2730. 


\section{Tables}

Table 1. Stepwise formulation of a self-assembling $\mathrm{pH}$-triggered 2\% w/v Fmoc-peptide by acid titration $(500 \mu \mathrm{L})$.

\begin{tabular}{ccc}
\hline Formulation step & Constituent & Quantity \\
\hline 1 & Fmoc-peptide & $10 \mathrm{mg}$ pre-weighed \\
2 & Deionised $\mathrm{H}_{2} \mathrm{O}$ & $200 \mu \mathrm{L}$ (in $50 \mu \mathrm{L}$ aliquots) \\
3 & $1 \mathrm{M} \mathrm{NaOH}$ & $50 \mu \mathrm{L}$ (in $10 \mu \mathrm{L}$ aliquots) \\
4 & Deionised $\mathrm{H}_{2} \mathrm{O}$ & $200 \mu \mathrm{L}$ (in $50 \mu \mathrm{L}$ aliquots) \\
5 & $0.5 \mathrm{M} \mathrm{HCl}$ & $20 \mu \mathrm{L}$ (in $10 \mu \mathrm{L}$ aliquots) \\
6 & Deionised $\mathrm{H}_{2} \mathrm{O}$ & to $500 \mu \mathrm{L}$ \\
\hline
\end{tabular}

Table 2. Stepwise formulation of a self-assembling $\mathrm{pH}$-triggered 2\% w/v Fmoc-peptide by GdL induction (2 mL).

\begin{tabular}{ccc}
\hline Formulation step & Constituent & Quantity \\
& & \\
\hline 1 & Fmoc-peptide & $40 \mathrm{mg}$ pre-weighed \\
2 & Deionised $\mathrm{H}_{2} \mathrm{O}$ & $1600 \mu \mathrm{L}$ (in $200 \mu \mathrm{L}$ aliquots) \\
3 & Sonicated 2 minutes $(42 \mathrm{KHz} \pm 6 \%)$ \\
4 & $1 \mathrm{M} \mathrm{NaOH}$ & $200 \mu \mathrm{L}$ (in $20 \mu \mathrm{L}$ aliquots) \\
5 & Deionised $\mathrm{H}_{2} \mathrm{O}$ & $200 \mu \mathrm{L}$ (in $50 \mu \mathrm{L}$ aliquots) \\
6 & GdL & $10 \mathrm{mg}$
\end{tabular}

Table 3. Minimum critical gelation concentration (\% w/v) for each Fmoc-peptide determined via vial inversion assay. 


\begin{tabular}{cccc}
\hline Fmoc-peptide & $\begin{array}{c}\text { Predicted partition } \\
\text { coefficient (Log } \\
\text { P })^{\mathrm{a}}\end{array}$ & $\begin{array}{c}\text { Minimum critical } \\
\text { gelation concentration } \\
(\% \mathrm{w} / \mathrm{v})\end{array}$ & $\begin{array}{c}\text { Minimum critical } \\
\text { gelation } \\
\text { concentration }(\% \\
\mathrm{w} / \mathrm{v})\end{array}$ \\
\hline FmocFF & 5.57 & 1.5 & 0.5 \\
FmocFFKK & 3.46 & 1 & 1 \\
FmocFFFKK & 4.36 & 1 & 1 \\
FmocFFOO & 2.45 & 1 & 1 \\
\hline
\end{tabular}

Predicted from Molinspiration Cheminformatics Software: www.molinspiration.com

Figures

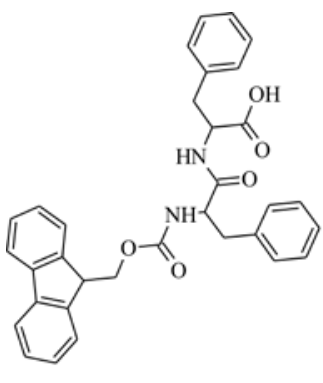

a)

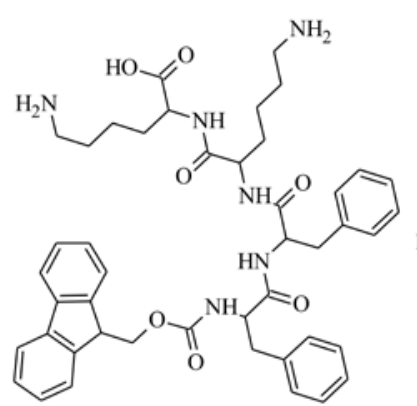

b)

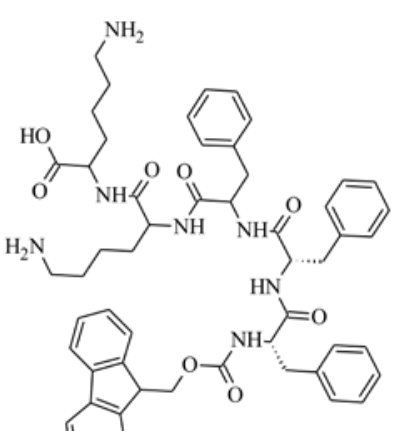

c)

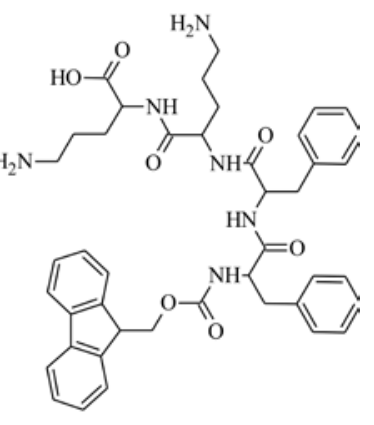

d)

Figure 1. Chemical structures of carboxylic acid terminated Fmoc-peptides investigated: (a) FmocFF, (b) FmocFFKK, (c) FmocFFFKK, (d) FmocFFOO. 


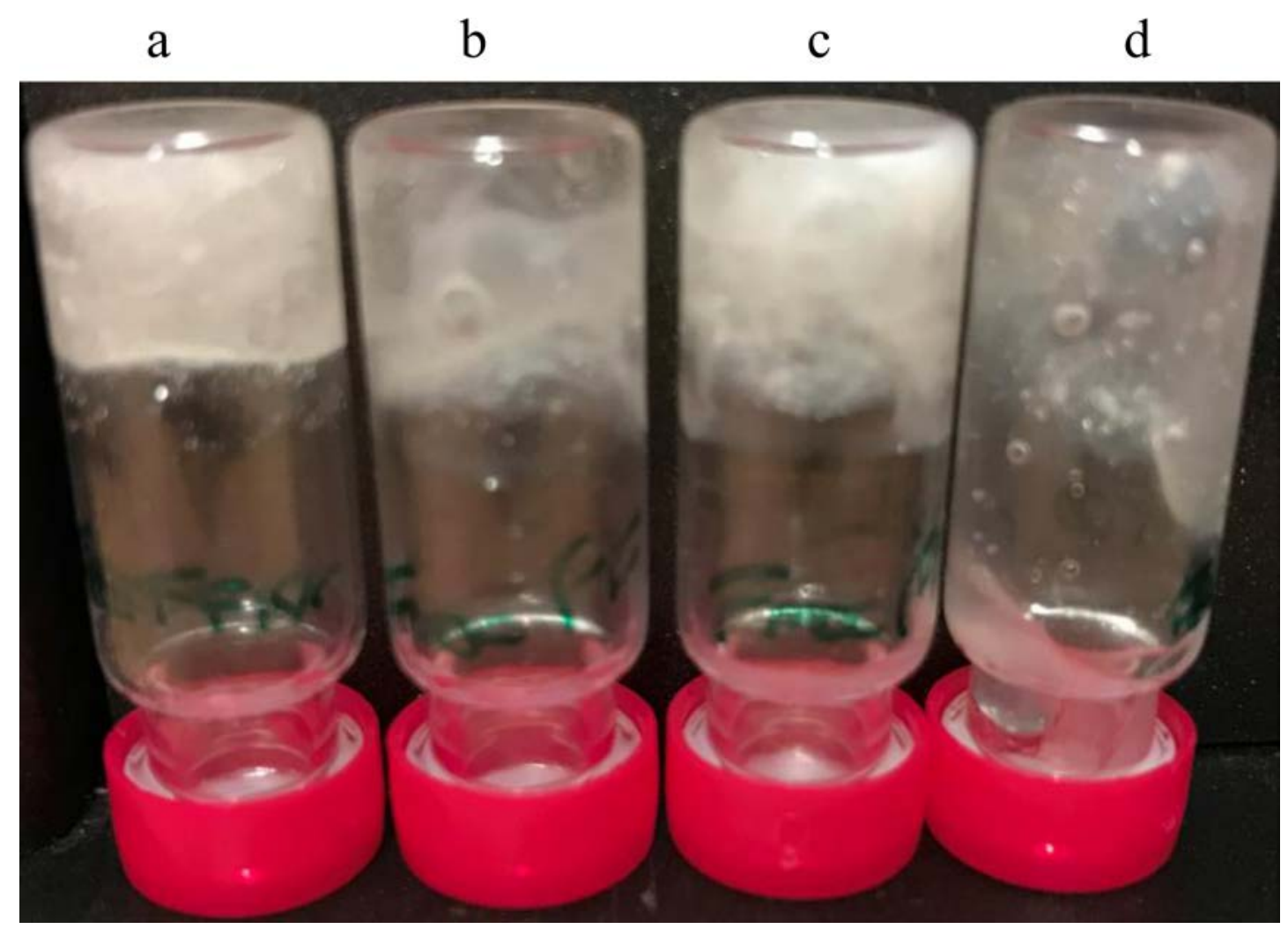

Figure 2. Gel inversion assay for (a) 1.5\% w/v FmocFF (b) 1\% w/v FmocFFKK (c) 1\% w/v FmocFFFKK (d) 1\% w/v FmocFFOO for acid titrated hydrogelation.

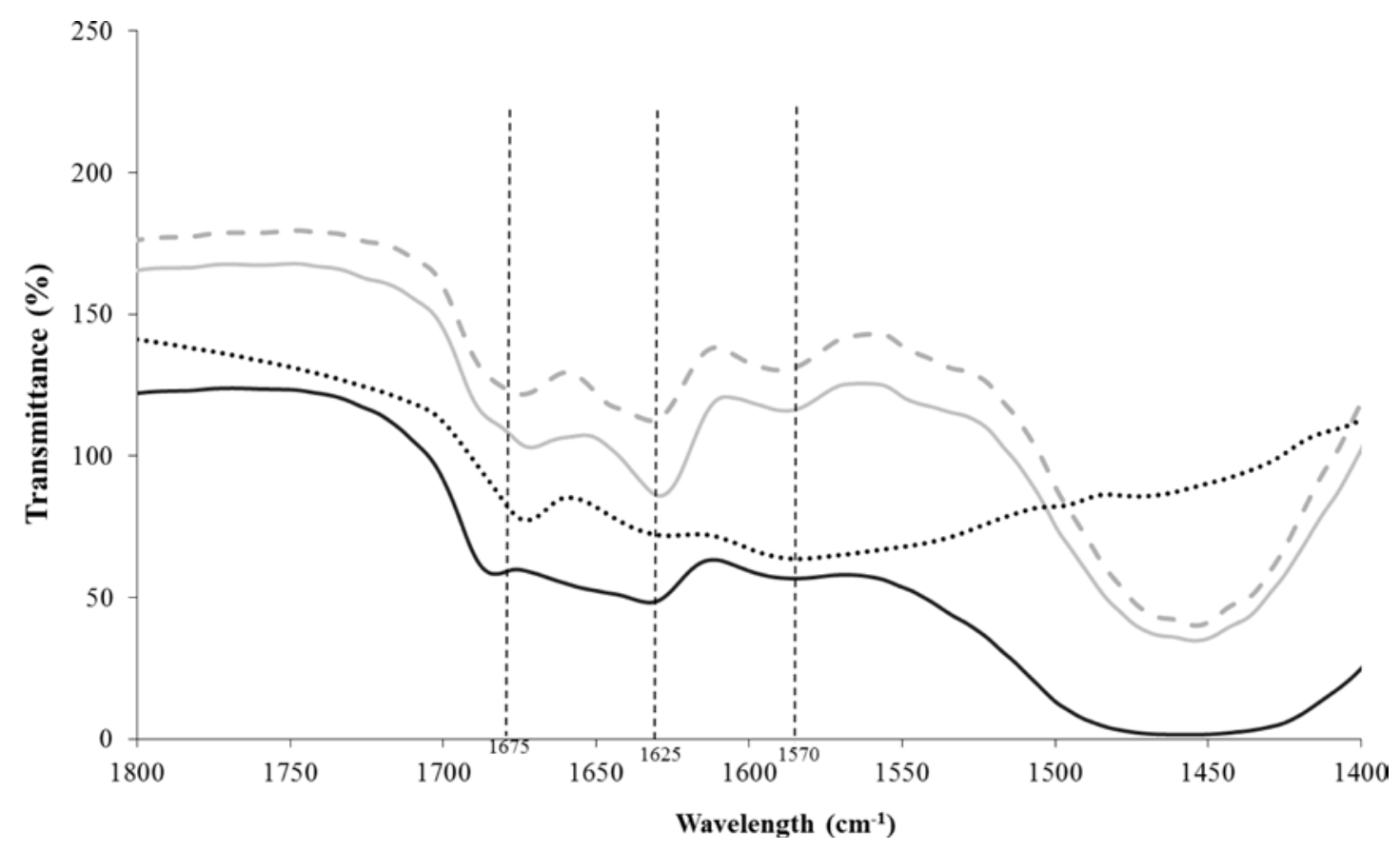


Figure 3. FTIR spectra displaying amide band of 2\% w/v Fmoc-peptides. Key: dotted black line: FmocFF, full grey line: FmocFFKK, full black line: FmocFFFKK, broken grey line: FmocFFOO.

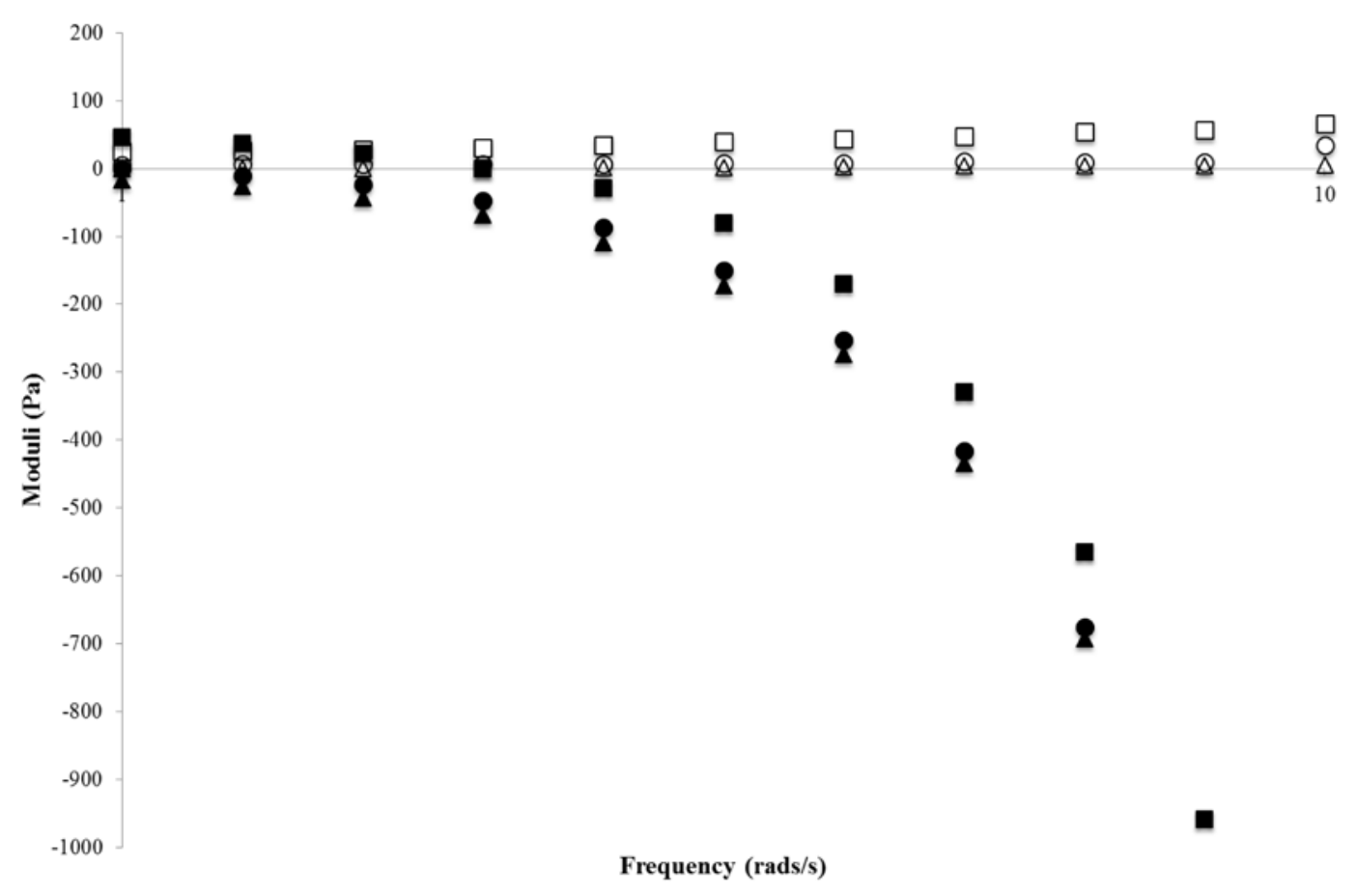

Figure 4. Oscillatory frequency sweep 2\% w/v Fmoc-peptides. Key: black square: $\mathrm{G}^{\prime}$ FmocFF, white square: G" FmocFF, black triangle: G' FmocFFKK, white triangle: G" FmocFFKK, black circle: G' FmocFFOO, white circle: G" FmocFFOO. 


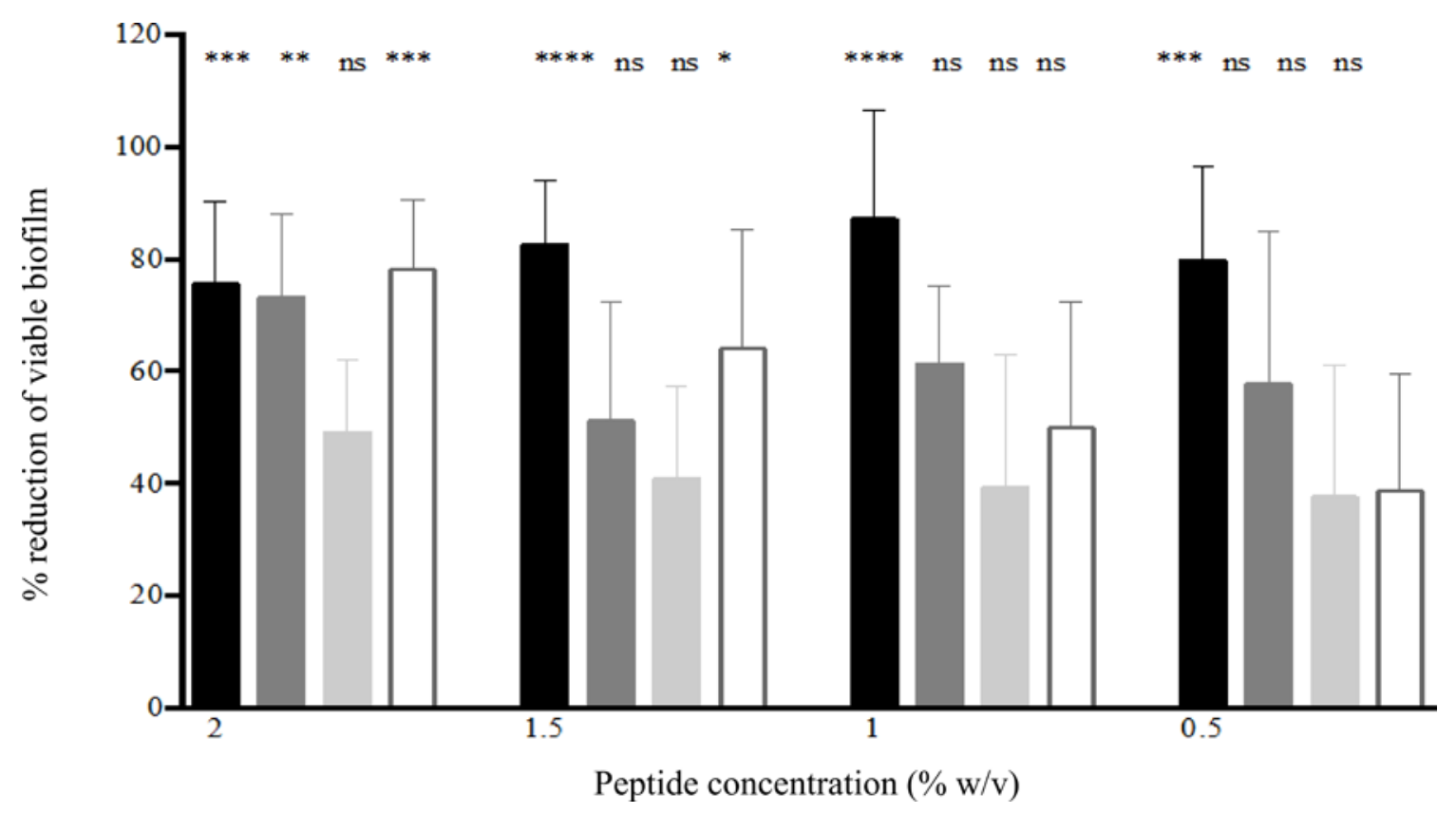

Figure 5. Percentage reduction in viability of S. aureus (ATCC 6538) 24 hour biofilm following 24 hour exposure to Fmoc-peptides. Key: FmocFF: black column, FmocFFKK: grey column, FmocFFFKK: light grey column, FmocFFOO: white column. ns: no significant $(\mathrm{P} \geq 0.05), *: \mathrm{P}<0.05, * *: \mathrm{P}<0.01, * * *: \mathrm{P}<0.001, * * * *: \mathrm{P}<0.0001$ difference between percentage reduction in biofilm viability for Fmoc-peptides and the negative control (PBS).

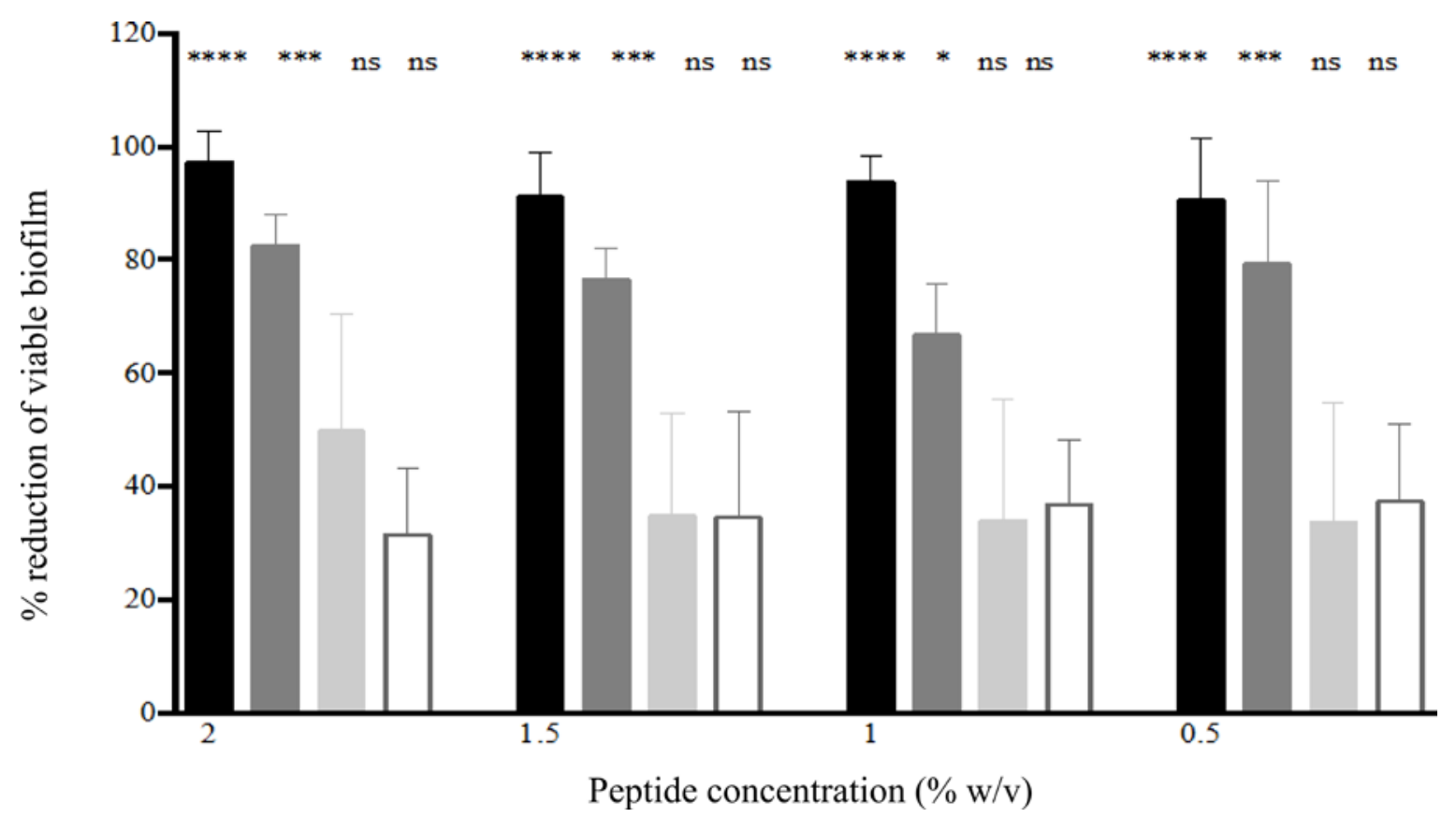

Figure 6. Percentage reduction in viability of 24 hour E. coli (ATCC 11303) biofilm following 24 hour exposure to Fmoc-peptides. Key: FmocFF: black column, FmocFFKK: grey column, FmocFFFKK: light grey column, FmocFFOO: white column. ns: no significant 
( $\mathrm{P} \geq 0.05), *: \mathrm{P}<0.05, * *: \mathrm{P}<0.01, * * *: \mathrm{P}<0.001, * * * *$ : $\mathrm{P}<0.0001$ difference between percentage reduction in biofilm viability for Fmoc-peptides and the negative control (PBS).

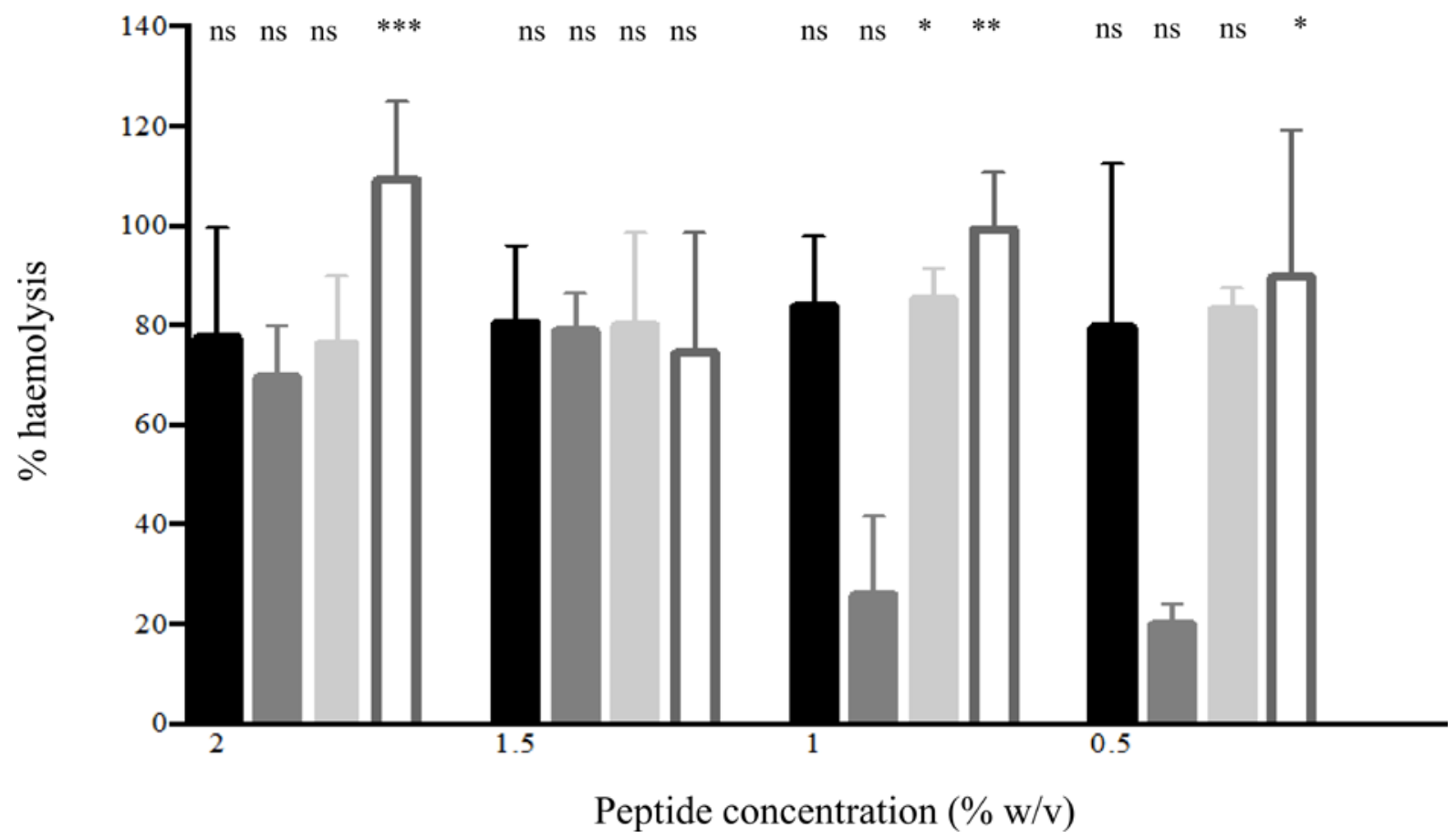

Figure 7. Percentage haemolysis of equine erythrocytes after 1 hour exposure to varying concentrations of Fmoc-peptides. Key: FmocFF: black column, FmocFFKK: grey column, FmocFFFKK: light grey column, FmocFFOO: white column. ns: no significant $(\mathrm{P} \geq 0.05)$, * $\mathrm{P}<0.05$, **: $\mathrm{P}<0.01$, ***: $\mathrm{P}<0.001$, ****: $\mathrm{P}<0.0001$ difference between haemolysis for the Fmoc-peptides and the negative control (PBS). 


\section{Supplementary information}

\section{Ultrashort self-assembling Fmoc-peptide hydrogels for biomaterial applications}

Alice P. McCloskey ${ }^{1}$, Emily R. Draper², Brendan F. Gilmore ${ }^{1}$, Garry Laverty ${ }^{1 *}$

1. Biofunctional Nanomaterials Group, School of Pharmacy, Medical Biology Centre, Queen’s University Belfast, 97 Lisburn Rd, Belfast, N. Ireland, BT9 7BL.

2. Department of Chemistry, University of Liverpool, Liverpool, L69 7ZD, U.K.

Table S1. Mass spectrometry analysis of synthesised Fmoc-peptides.

\begin{tabular}{|l|l|l|}
\hline Synthesised Peptide & $\begin{array}{l}\text { Calculated Exact } \\
\text { Molecular Mass }\end{array}$ & Detected Molecular Mass \\
\hline FmocFF & 534.22 & $535\left(\mathrm{M}+\mathrm{H}^{+}\right)$ \\
\hline FmocFFKK & 790.41 & $791\left(\mathrm{M}+\mathrm{H}^{+}\right)$ \\
\hline FmocFFOO & 762.37 & $764\left(\mathrm{M}+2 \mathrm{H}^{+}\right)$ \\
\hline FmocFFFKK & 937.47 & $955\left(\mathrm{M}+\mathrm{NH}_{4}^{+}\right)$ \\
\hline
\end{tabular}

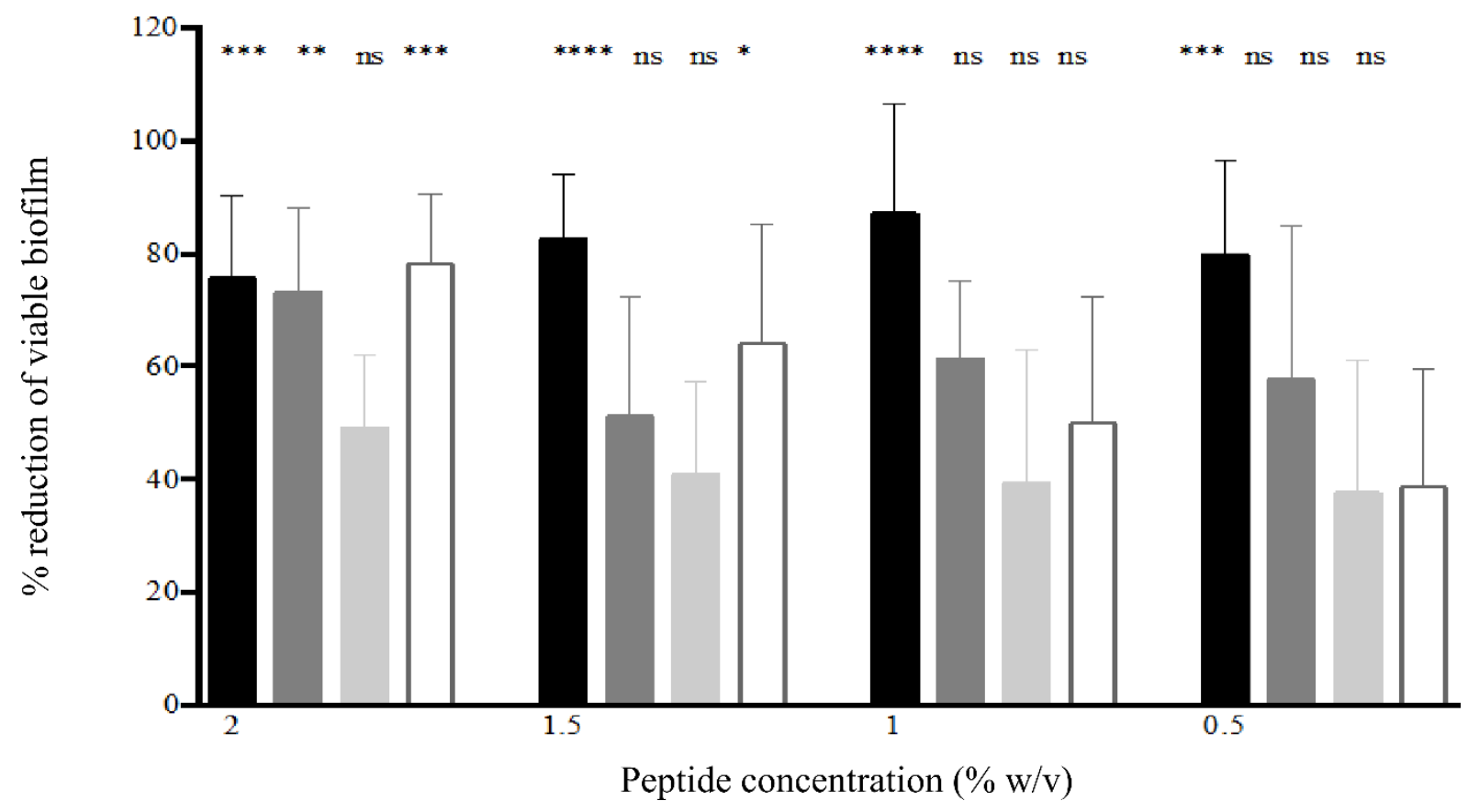

Figure S1. Percentage reduction in viability of 24 hour S. epidermidis (ATCC 35984) biofilm following 24 hour exposure to Fmoc-peptides. Key: FmocFF: black column, FmocFFKK: grey column, FmocFFFKK: light grey column, FmocFFOO: white column. ns: no significant 
( $\mathrm{P} \geq 0.05), *: \mathrm{P}<0.05, * *: \mathrm{P}<0.01, * * *: \mathrm{P}<0.001, * * * *: \mathrm{P}<0.0001$ difference between percentage reduction in biofilm viability for Fmoc-peptide and the negative control (PBS).

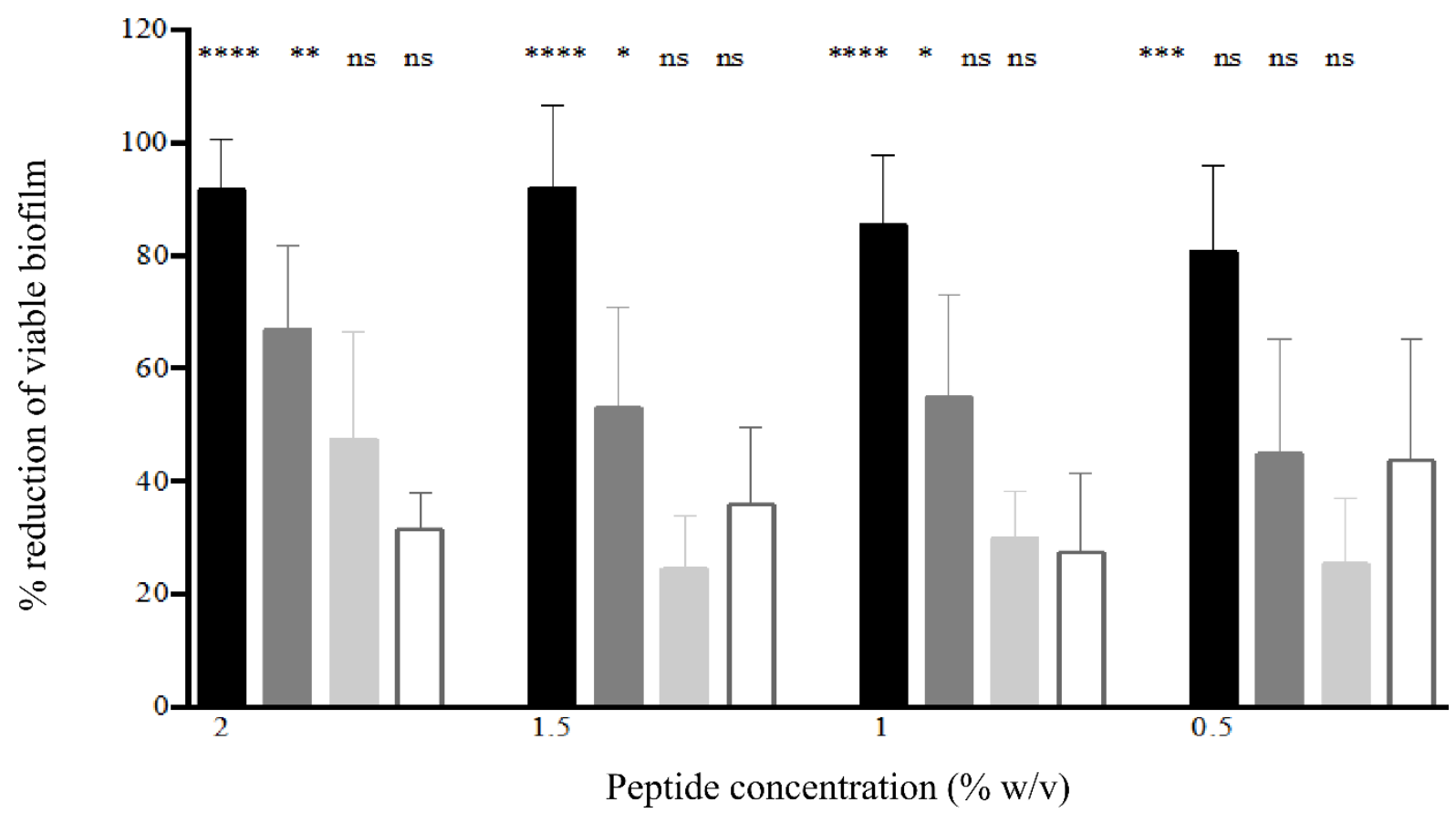

Figure S2. Percentage reduction in viability of 24 hour P. aeruginosa (PAO1) biofilm following 24 hour exposure to Fmoc-peptides. Key: FmocFF: black column, FmocFFKK: grey column, FmocFFFKK: light grey column, FmocFFOO: white column. ns: no significant $(\mathrm{P} \geq 0.05),{ }^{*}: \mathrm{P}<0.05, * *: \mathrm{P}<0.01$, ***: $\mathrm{P}<0.001$, ****: $\mathrm{P}<0.0001$ difference between percentage reduction in biofilm viability for Fmoc-peptide and the negative control (PBS). 